\title{
Effect of Fermentation Time and Cassava Varieties on Water Content and the Yield of Starch from Modified Cassava Flour (MOCAF)
}

\author{
Nurud Diniyah*, Achmad Subagio, Riri N. L. Sari, Pradiska G. Vindy, \\ Alif A. Rofiah
}

Department of Agricultural Products Technology, Faculty of Agricultural Technology, University of Jember, Jember, Indonesia

Submitted 1 January 2018; Revised 31 January 2018; Accepted 14 February 2018; Published 27 June 2018

*Corresponding author: nurud.ftp@unej.ac.id

\begin{abstract}
MOCAF (modified cassava flour) is a high potential food product. This product can be used to replace wheat flour in the manufacture of various food products. However, there is no characterization of starch properties of MOCAF. The efforts to improve the quality of starch from cassava starch by fermentation process using a combination of enzymes and microbes from Lactic acid bacteria. The purpose of this research is to determine the influence of fermentation time to yield and moisture content. Single factor randomized block design with 3 (three) levels i.e fermentation time (0,12, and 24 hours) with two group namely varieties of cassava Cimanggu and Kaspro. Cimanggu and Kaspro cassava varieties were used to compare the properties of starch due to different fermentation time ( 0,12 and 24 hours) with triplicate. The results showed the yield and moisture content were affected by fermentation time. Average moisture content ranged from 13.3 to $13.8 \%$ with the starch yield is $38-59 \%$. Application of starch MOCAF can be used for food, cosmetics, and medicines industry.
\end{abstract}

Key words: Cassava, fermentation, modified starch, yield.

\section{Pengaruh Lama Fermentasi dan Jenis Singkong Terhadap Kadar Air dan Rendemen Pati dari Modified Cassava Flour (MOCAF)}

\begin{abstract}
Abstrak
MOCAF (modified cassava flour) merupakan produk pangan yang memiliki potensi tinggi. Produk ini bisa digunakan untuk menggantikan tepung terigu dalam pembuatan berbagai produk makanan. Namun, permasalahannya belum dilakukan karakterisasi sifat pati dari MOCAF. Upaya untuk meningkatkan kualitas pati dari singkong dengan proses fermentasi dilakukan dengan menggunakan kombinasi antara enzim dan mikroba Bakteri Asam Laktat (BAL). Tujuan dari penelitian ini adalah untuk mengetahui pengaruh dari lama fermentasi dan varietas singkong pada pembuatan MOCAF terhadap rendemen dan kadar air. Rancangan Acak Kelompok (RAK) faktor tunggal dengan 3 (tiga) taraf yaitu lama fermentasi $(0,12$, dan 24 jam $)$ dengan dua kelompok yaitu varietas singkong Cimanggu dan Kaspro digunakan untuk membandingkan sifat pati terhadap perbedaan lama fermentasi $(0,12$ dan 24 jam) dan diulang sebanyak tiga kali. Hasil penelitian menunjukkan bahwa rendemen dan kadar air pati MOCAF dipengaruhi oleh waktu fermentasi. Kadar air pati MOCAF rata-rata berkisar 13,3 13,8\% dengan rendemen pati sekitar 38-59\%. Aplikasi pati MOCAF dapat digunakan untuk kebutuhan industri makanan, kosmetik dan obat-obatan.
\end{abstract}

Kata Kunci: Fermentasi, modifikasi singkong, pati, rendemen. 


\section{Pendahuluan}

Singkong (Manihot esculenta Crantz.) adalah hasil pertanian yang penting bagi Indonesia. Saat ini produksi singkong di Jawa Timur, Indonesia telah mencapai hasil 2.942.933 ton dengan luas panen 120.208 hektar pada tahun 2016 ${ }^{1}$ Berdasarkan kandungan $\mathrm{HCN}$ (asam sianida), singkong terdiri dari dua varietas, yakni varietas manis dan pahit. Singkong manis adalah singkong yang memiliki kandungan $\mathrm{HCN}<100 \mathrm{mg} / \mathrm{kg}$ berat segar umbi, seperti Cimanggu, Mentega, Pohon Ketan. Sedangkan singkong pahit adalah singkong yang memiliki kandungan $\mathrm{HCN}>100 \mathrm{mg} / \mathrm{kg}$ berat segar umbi, seperti Malang 6, Kaspro, Malang $4^{2}$. Penelitian yang dilakukan oleh Nugraheni (2013), menyatakan terdapat korelasi antara kadar $\mathrm{HCN}$ singkong segar dengan kandungan patinya, dimana kadar HCN singkong yang semakin tinggi, maka semakin pahit rasanya serta kadar pati meningkat dan sebaliknya. Oleh sebab itu, industri tapioka umumnya menggunakan varietas berkadar HCN tinggi (varietas pahit) $^{3}$.

Singkong dapat diolah menjadi produk yang potensial, salah satunya pati modifikasi yakni Modified Cassava Flour (MOCAF). MOCAF merupakan produk tepung singkong yang diproses menggunakan prinsip memodifikasi sel singkong dengan fermentasi menggunakan mikroba BAL (Bakteri Asam Laktat) yang mendominasi selama fermentasi tepung singkong. Produksi MOCAF cukup tinggi karena pemanfaatannya yang sangat luas sebagai food ingredient maupun bahan baku dari berbagai jenis makanan. Hal ini karena MOCAF memiliki spektrum aplikasi yang hampir sama dengan terigu dan tepung beras $^{4}$.

MOCAF dapat dibuat dari singkong varietas manis (sweet cassava) maupun varietas pahit (bitter cassava). MOCAF dari singkong manis baik untuk pembuatan kue dan biskuit, karena cita rasa singkong yang tidak terlalu kuat, sedangkan MOCAF dari varietas pahit juga bisa, tapi hasilnya tidak sebaik yang $\mathrm{HCN}$-nya rendah ${ }^{4}$. Setiap varietas singkong memiliki karakteristik khusus, baik dari segi fisik, kimia dan morfologi umbinya.
Begitu pula dengan MOCAF yang dihasilkan dari varietas singkong yang berbeda, diduga memiliki karakteristik pati yang berbeda pula.

Proses modifikasi pati pada MOCAF mengakibatkan adanya perbedaan karakteristik dengan pati pada tepung singkong, yakni terjadi perubahan fungsional pada MOCAF berupa naiknya viskositas, kemampuan gelasi, daya rehidrasi, WHC (Water Holding Capacity) dan kemudahannya larut ${ }^{4}$. Secara kimia, MOCAF memiliki kadar pati lebih tinggi yakni $85-87 \%$, sedangkan tepung singkong hanya $82-85 \%$. Dilihat dari segi fisik, nilai kekentalan (mPa.s) MOCAF lebih tinggi. Kestabilan viskositas MOCAF lebih baik pada berbagai variasi $\mathrm{pH}$ dan tingkatan suhu jika dibandingkan dengan tapioka ${ }^{5}$.

Sifat pati MOCAF dapat mempengaruhi kualitas MOCAF yang dihasilkan. Sifat tersebut ditentukan oleh amilosa dan amilopektin yang merupakan komponen utama dari pati. Perbedaan sifat pati ini dapat terjadi akibat beberapa faktor, seperti jenis singkong yang digunakan dan lama fermentasi yang diberikan. Hal tersebut menyebabkan pati yang terbentuk memiliki sifat yang tidak sama. Karakteristik yang demikian akan mempengaruhi sifat MOCAF yang dihasilkan. Oleh karena itu, perlu dilakukan penelitian untuk mengetahui pengaruh variasi jenis singkong dan lama fermentasi yang diberikan terhadap pati MOCAF yang dihasilkan dengan menentukan rendemen dan kadar air.

\section{Bahan dan Metode}

2.1. Bahan

Bahan baku yang digunakan dalam penelitian ini adalah dua varietas singkong segar yang berumur 8,5 - 9 bulan (Kaspro dan Cimanggu) dari Gumuk Mas, Jember Jawa Timur. Bahan yang digunakan untuk memodifikasi singkong menjadi MOCAF yakni senyawa aktif A (asam sitrat), air suling, enzim MOCAF (Laboratorium Kimia dan Biokimia Pangan, Fakultas Teknologi Pertanian, Universitas Jember), kultur media (susu skim dan gula pasir) dan senyawa aktif C (garam, merk Refina). 


\subsection{Metode}

\subsubsection{Ekstraksi sampel pati MOCAF}

Kulit terluar dan kulit ari dari singkong dicuci bersih. Bonggol singkong dirajang dengan bentuk chip. Chip singkong kemudian dicuci. Setelah itu, chip ditimbang untuk fermentasi. Air dan senyawa aktif A dicampur dan chip dimasukkan serta direndam selama 10 menit. Kemudian inokulum yang berisi enzim MOCAF dan kultur media ditambahkan. Lama perendaman atau tahapan fermentasi dilakukan sesuai perlakuan yang diberikan (0, 12, dan 24 jam). Setelah itu, chip ditiriskan lalu dicuci. Kemudian direndam dengan larutan senyawa aktif C. Chip hasil dari perendaman ditiriskan dan dicuci untuk satu kali dan dikeringkan. Pengeringan chip terfermentasi dilakukan dengan panas matahari selama 5 jam setiap harinya dengan rentan waktu $3-4$ hari. Chip singkong yang telah kering kemudian digiling. Tepung halus (MOCAF) diayak dengan ayakan 100 mesh.

Ekstraksi pati dari MOCAF menggunakan metode pengendapan dan sentrifugasi dengan modifikasi. MOCAF ditimbang dan ditambahkan aquades dengan perbandingan $1: 10$. Kemudian larutan diblender dan disaring dengan kain saring dan dilanjutkan dengan pengayakan 200 mesh. Filtrat disentrifugasi selama 5 menit dan hasil endapan dikeringkan suhu $40^{\circ}-50^{\circ} \mathrm{C}$ selama 24 jam dengan oven pengering. Pati MOCAF yang diperoleh kemudian dipisahkan ${ }^{5}$.

\subsection{Penetapan Kadar Air}

Penetapan kadar air dilakukan dengan metode pemanasan, yaitu dengan mengoven terlebih dahulu botol timbang yang akan digunakan selama 30 menit pada suhu $100^{\circ}-105^{\circ} \mathrm{C}$, setelah itu didinginkan dalam eksikator untuk menurunkan suhu dan menstabilkan kelembaban (RH). Kemudian ditimbang sebagai A gram. Tahap selanjutnya, sampel pati MOCAF ditimbang sebanyak 2 gram dalam botol timbang dan dicatat sebagai B gram. Bahan kemudian dioven pada suhu $100^{\circ}-105^{\circ} \mathrm{C}$ selama 6 jam lalu didinginkan dalam eksikator selama 30 menit dan ditimbang sebagai $\mathrm{C}$ gram. Pada tahap ini diulang hingga dicapai bobot yang konstan. Kadar air dihitung sebagai hasil pengurangan berat awal bahan dengan berat bahan konstan setelah dioven. Sedangkan rendemen pati MOCAF didapatkan dari perbandingan bahan MOCAF dengan hasil ekstraksi pati MOCAF yang dihasilkan dalam basis kering.

\subsection{Analisis Data}

Penelitian ini menggunakan pola RAK (Rancangan Acak Kelompok) faktor tunggal yaitu lama fermentasi $(0,12,24$ jam $)$ dengan 2 kelompok yakni singkong varietas Kaspro dan Cimanggu. Setiap perlakuan diulang sebanyak 3 kali. Variabel yang diamati dalam penelitian ini meliputi :kadar air ${ }^{6}$ dan rendemen ${ }^{7}$. Pengolahan data dilakukan dengan menggunakan Analisis ragam (ANOVA). Jika berbeda signifikan maka dilanjutkan dengan Uji Beda Nyata Terkecil (BNT) pada level $95 \%(\alpha=0,05)$. Data diolah menggunakan perangkat lunak SPSS 15.0.

\section{Hasil}

Rata-rata kadar air (\%db) pati MOCAF berkisar 13,3 - 13,8\% dapat dilihat pada Gambar 1. Kadar air tertinggi terdapat pada

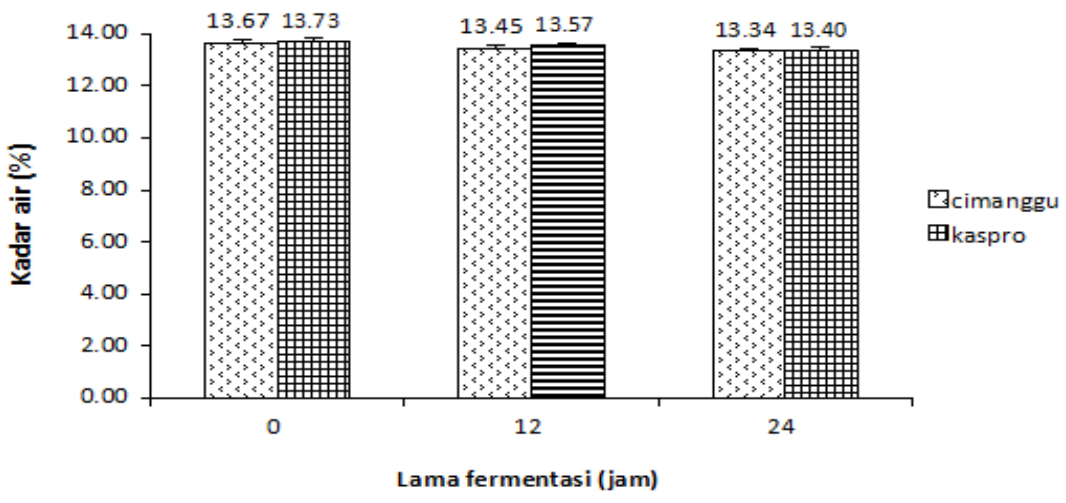

Gambar 1. Kadar Air Sampel 
pati MOCAF Kaspro tanpa fermentasi (0 jam) yakni $13,73 \%$ dan semakin menurun dengan semakin bertambahnya waktu fermentasi, begitupula pada pati MOCAF Cimanggu. Berdasarkan hasil sidik ragam menunjukkan bahwa perlakuan lama fermentasi pada masing-masing varietas berpengaruh nyata terhadap kadar air pati $\operatorname{MOCAF}(p<0,05)$. Kadar air dari pati MOCAF tanpa fermentasi berbeda nyata dengan pati MOCAF terfermentasi 12 maupun 24 jam, sedangkan kadar air dari pati MOCAF terfermentasi 12 jam tidak berbeda nyata dengan pati MOCAF terfermentasi 24 jam.

Berdasarkan hasil analisis ragam, menunjukkan perlakuan lama fermentasi pada masing-masing varietas singkong berpengaruh nyata $(\mathrm{p} \leq 0,05)$ terhadap rendemen pati MOCAF. Nilai rata-rata rendemen pati MOCAF pada varietas Cimanggu dan Kaspro dapat dilihat pada Gambar 2.

\section{Pembahasan}

Penurunan kadar air dengan semakin lama nya waktu fermentasi disebabkan adanya panas selama fermentasi akibat aktifitas mikroba. Mikroba menghasilkan enzim yang memecah senyawa organik menjadi lebih sederhana, $\mathrm{H}_{2} \mathrm{O}$ dan energi panas, sehingga air bahan menguap selama fermentasi berlangsung. Hasil tersebut sejalan dengan penelitian ${ }^{8}$ bahwa pati singkong asli memiliki kadar air yang lebih tinggi daripada pati modifikasi. Semakin rendah kadar air maka semakin tinggi jumlah padatan kering dalam tepung ${ }^{9}$. Degradasi pati menjadi gula sederhana diikuti oleh perubahan bahan ${ }^{10}$. Kadar air pati yang lebih rendah menunjukkan bahwa pati tersebut bisa disimpan lebih lama ${ }^{11}$. Kadar air pati MOCAF baik varietas Cimanggu maupun Kaspro dengan berbagai waktu fermentasi memenuhi Standar Mutu Pati SII (Standar Industri Indonesia) yang telah ditentukan yakni maksimum $14 \%{ }^{12}$.

Salah satu faktor yang mempengaruhi rendemen adalah lama ekstraksi, akurasi lama waktu yang digunakan berpengaruh terhadap efisiensi proses ${ }^{13}$. Rendemen pati MOCAF pada masing-masing varietas semakin menurun seiring dengan lama fermentasi. Hal ini disebabkan karena semakin lama fermentasi semakin banyak pati yang terhidrolisis menjadi gula-gula sederhana sehingga kadar pati semakin menurun. Besarnya rendemen pati tergantung dari bahan keringnya. Semakin tinggi kadar bahan kering maka semakin tinggi pula rendemen pati yang dihasilkan. Pada pati MOCAF varietas Kaspro memiliki nilai rendemen yang cenderung lebih tinggi $(38,89-58,80 \%)$ dibandingkan dengan varietas Cimanggu $(39,45-58,53 \%)$. Perbedaan ini disebabkan karena kadar air pada bahan baku yaitu pati MOCAF varietas Kaspro cenderung lebih tinggi (13,40 -13,73\%) dibandingkan dengan varietas Cimanggu (13,34 - 13,67\%). Kadar air bahan baku yaitu pati MOCAF yang tinggi memberikan kadar bahan kering yang rendah, karena selama pengeringan banyak air yang menguap sehingga mempengaruhi randemen menjadi lebih rendah ${ }^{14}$. Dibandingkan dengan rendemen pati dari ubi kayu $18,74 \%{ }^{15}$, maka rendemen pati MOCAF masih lebih

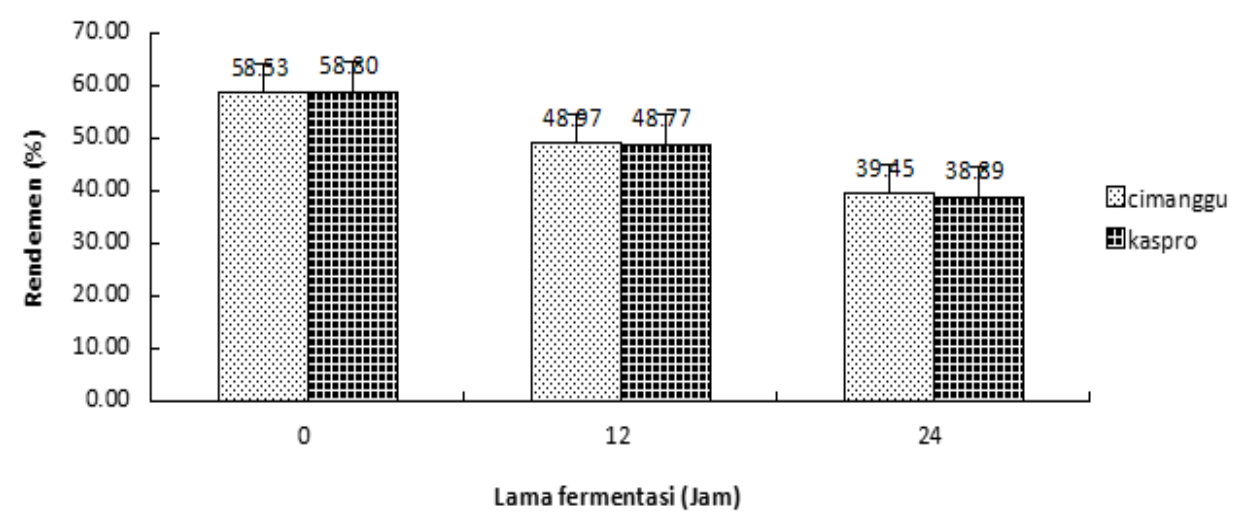

Gambar 2. Rendemen Pati Sampel 
tinggi yaitu $38,89-58,80 \%$, tetapi jika dibandingkan dengan rendemen pati ganyong hasil modifikasi menggunakan asam asetat $(96,51 \%)$ dan asam klorida $(66,55 \%)^{16}$ maka pati MOCAF lebih rendah.

\section{Kesimpulan}

Perlakuan variasi varietas singkong dan lama fermentasi mempengaruhi karakteristik pati MOCAF yang dihasilkan yaitu pada kadar air dan rendemen pada pati MOCAF berturut-turut adalah 13,3 - 13,8\% dan 38$59 \%$. Aplikasi pati dapat digunakan baik dalam industri makanan, kosmetik maupun obat-obatan.

\section{Ucapan Terima Kasih}

Proyek IDB telah menyediakan dana program pelatihan non gelar pada tahun 2017.

\section{Daftar Pustaka}

1. Badan Pusat Statistik Provinsi Jawa Timur. Luas panen, produktivitas, dan poduksi komoditi ubi kayu di Jawa Timur 2002 - 2016 [diunduh 12 Desember 2017]. Tersedia dari: http://jatim.bps. go.id/.

2. Winch T. Growing food : a guide to food production. Dordrecht : Springer; 2006.

3. Nugraheni M, Titin HWH, Agung U. Pengembangan MOCAF (Modified Cassava Flour) untuk peningkatan diversifikasi pangan dan ekonomi pasca erupsi merapi (laporan kegiatan PPM). Yogyakarta : Universitas Negeri Yogyakarta; 2013.

4. Subagio A, Windrati WS, Witono Y, Fahmi F. Rusnas diversifikasi pangan pokok. prosedur operasi standar (POS) produk Mocal berbasis klaster. Jember: Fakultas Teknologi Pertanian-SEAFAST Center IPB; 2008.

5. Putri NA, Diniyah N, Subagio A. Sifat pasta MOCAF (Modified Cassava Flour) menggunakan rapid visco analyzer. Prosiding Seminar Nasional Perhimpunan Ahli Teknologi Pertanian; 2015 Oktober 20-21; Semarang, Indonesia. Indonesia: Universitas Katolik Soegijapranata; 2015.

6. AOAC. Official of analysis of the association of official analytical chemistry. Airlington: AOAC Inc ; 2005.

7. AOAC. Official methods of analiysis (15 ${ }^{\text {th }}$ Ed.). K. Helrich (Ed.). Virginia; 1990.

8. Rao JS, Parimalavalli R, Jagannadham $\mathrm{K}$. Impact of cross-linking on physicochemical and functional properties of cassava starch. Int $\mathrm{J}$ of $\mathrm{Adv}$ Reseach. 2014; 2 (5) : 284-289.

9. Akpa JG, Dagde, Kenneth K. Modification of cassava starch for industrial uses. Int J. of Eng and Techn. 2012; 2 (6) : 913 - 919.

10. Mahfudin, Sigit P, Cicih S. Kajian ekstrak daun randu (Ceiba Pentandra L.) sebagai bahan edible coating terhadap sifat fisik dan kimia buah tomat selama penyimpanan. J. Teknotan. 2016; 10 (1) :1978-1067.

11. Karmakar R, Ban DK, Ghosh U. Comparative study of native and modified starches isolated from conventional and nonconventional sources. Intrn Food Research J. 2014; 21 (2) : 597-602.

12. Widowati S, Waha MG, Santosa BAS. Ekstraksi dan karakterisasi sifat fisikokimia dan fungsional pati beberapa varietas talas (Colocasia esculenta L. Schott). Prosiding Seminar Teknologi Pangan; 1997 Juli 16-17; Bali, Indonesia. Indonesia: 1997.

13. Hardani DA, Nur H, Ika AD. Ekstraksi minyak bunga melati (Jasminum sambac) (kajian jenis pelarut dan lama ekstraksi) (skripsi). Malang : Universitas Brawijaya; 2013.

14. Anggraeni YP, Yuwono SS. Pengaruh fermentasi alami pada chips ubi jalar (Ipomoea batatas) terhadap sifat fisik tepung ubi jalar terfermentasi. J. Pangan dan Agro. 2014; 2 (2) : 59-69.

15. Mustafa A. Analisis proses pembuatan pati ubi kayu (tapioca) berbasis neraca massa. J. Agrointek. 2015; 9 (2): 127-133.

16. Putri AP, Oetari T, Annisa N, Gadri A, Aprilia H. Evaluasi fisikokimia pati ganyong (Canna indica L) modifikasi esterifikasi dan hidrolisis asam. IJPST. 2016; 3 (3): $78-82$. 